\title{
HEALTH AND SAFETY SYSTEM IMPLEMENTATION OF CONSTRUCTION PROJECT WORK INTO CORPORATE CULTURE TO INCREASE PERFORMANCE
}

\author{
Widayatama Idaman*, Syah Tantri Yanuar Rahmat, Anindita Rina \\ Faculty of Economic and Business, University of Esa Unggul, Indonesia \\ ${ }^{*}$ E-mail: idamwid@gmail.com
}

\begin{abstract}
Generally speaking, in Indonesia, safety and security at work (also widely known as K3, Keselamatan and Keamanan Kerja), had not been primary concern in the general and construction Works. It is shown in the high figure of work accidents in construction works, reaching approximately $7-8 \%$ of the whole sector of workers. Which is in turns contributes $6.45 \%$ to Indonesian GDP as cost on national level. That is why the concern to K3 must be developed as corporate culture, not only to protect workers' safety and security but also to increase the performance of the firms.
\end{abstract}

\section{KEY WORDS}

Workplace accidents, occupational safety, health culture, construction project performance.

Construction activities are an important element in nation-building and have been proven to provide important contributions in the development and economic growth of all countries in the world, both organized by the government as well as by private sectors (Kadin, 2002). However, it should also be remembered that the implementation of construction activities has the potential to cause various undesirable impacts.

In general, K3 issues in Indonesia are still often overlooked, especially in the implementation of the constructions of public works with simple building constructions. This is indicated by the still high rate of work accidents in the construction service sector which covers around $7-8 \%$ of the total workforce in all sectors, and contributes $6.45 \%$ of GDP in Indonesia. Ironically, out of the total workforce in construction sector which reaches around 4.5 million people, $53 \%$ of them only received education up to elementary school level, in fact around $1.5 \%$ of these workers have never received any formal education (Iman Kurniawan Wicaksono and Moses L. Singgih, 2011). Therefore, construction activities should be managed in accordance with the applicable K3 standards and provisions.

The Ministry of Public Works, according to its field of work, also continues working to improve Occupational Health and Safety (K3). One of the efforts of the Ministry of Public Works is to improve the Occupational Health and Safety, carried out by issuing the Minister of Public Works Regulation No.09/PRT/M/2008 dated 1 Juli 2008 concerning Guidelines for Occupational Health and Safety Management System (SMK3) for construction in the field of public works. In addition, several occupational health and safety regulations have been established, among others are as follows: Law No. 1 of 1970 concerning Occupational Safety and Minister Regulation No. PER05/MEN/1996 concerning Occupational Health and Safety Management System. These regulations were established for the purpose of preventing and anticipating work accidents. The occupational health and safety programs should start from the most basic stage, namely the establishment of an occupational safety and health culture (Reason, 1997).

According to Mondy (2010) occupational safety is the protection of employees from injuries caused by accidents related to work. Safety risks are aspects of working environment that can cause fires, electrical hazards, cuts, bruises, sprain, fractures, loss of limbs, visions, and hearings. While occupational health is freedom from physical violence. Health risks are factors in a working environment that work over a specified period of time, an environment that can create emotional stress or physical disturbances. Both concepts are known as Occupational Health and Safety (K3). Occupational health and safety programs will be able 
to function effectively if the program can be communicated to all layers of individuals involved in the construction projects.

In turn, good employee performance may have positive impact on the company as a whole. One of them is an increase in the settlement of responsibilities given by the company to workers. Factors of safety and protection at work become one of the factors that influence employee performance. When employees have a sense of security and comfort because they feel they get good protection from the company, the employees would also work with a relaxed feeling and may work well. It is expected that company employees like this will have maximum performance. One effort in implementing protection for employees is by implementing the Occupational Health and Safety (K3) program.

There is an interesting phenomenon that is owned by construction industry, namely:

- Construction industry services are an industry that has considerable risks, but can be minimized by the existence of occupational health and safety programs through the establishment of work cultures, one of which is occupational health and safety culture;

- Construction industry is an industry that does not have an orientation solely on the end products as in other industries; instead it is a process-oriented industry.

In the Construction Project Management, one of the main objectives achieved are to create a working climate that supports in terms of facilities, working conditions, work safety, and open reciprocal communication between superiors and subordinates (Paulus, 1985). This study tries to analyze the relation between the fulfillment of occupational health and safety (K3) in the corporate culture and the performance of companies in construction service sector.

Occupational Health and Safety according to OHSAS 18001:2007 defines Occupational Health and Safety as conditions and factors that influence or will influence the health and safety of workers (including contract workers or contractors) and also guests or other people at the workplace. Occupational Health and Safety (K3) is a system designed to ensure proper safety to all personnel in the workplace so as not to suffer any injuries as well as causes illness in the workplace by adhering or obeying the laws and regulations of occupational health and safety, which are reflected on the changes of attitudes towards safety in the workplace. Rijuna Dewi (2006 in the Journal of Management and Organizational Studies, Volume 7:44).

There are many causes of workplace accidents in construction projects, one of which is the character of the project itself. Construction projects have a poor connotation when viewed from the aspect of cleanliness and neatness, to be more precise, it could be called chaotic due to the many tools, workers, materials. Other factors that cause workplace accidents are the construction workers themselves, who tend to ignore the provisions of work safety standards, choice of inappropriate work methods, workplaces changes so they must always adjust, disputes between workers that affect their performance, employee disputes with the project team, equipments used, and many other factors.

In addition, according to $\mathrm{H}$. W. Heinrich's domino effect theory, the biggest contribution to the causes of work accident cases is the human negligence factor that is equal to $88 \%$. Whereas the other $10 \%$ are from the factors of property / asset / goods inadequacy and $2 \%$ other factors. From the results of the evaluation of occupational accidents so far, it can be concluded that several factors that have caused accidents, both with fatalities as well as injuries, did not involve construction engineering experts, did not use appropriate implementation methods, poor supervision of construction in the field, had not yet fully implementing regulations concerning the existing K3, poor supervision of K3 implementation, inadequacy of both the quality and quantity of the available Personal Protective Equipment (PPE), socio-economic environmental factors and work culture and lack of discipline of workers in complying with $\mathrm{K} 3$ provisions, including the use of occupational accidents PPE (Construction and Human Resource Development Agency, 2007). 


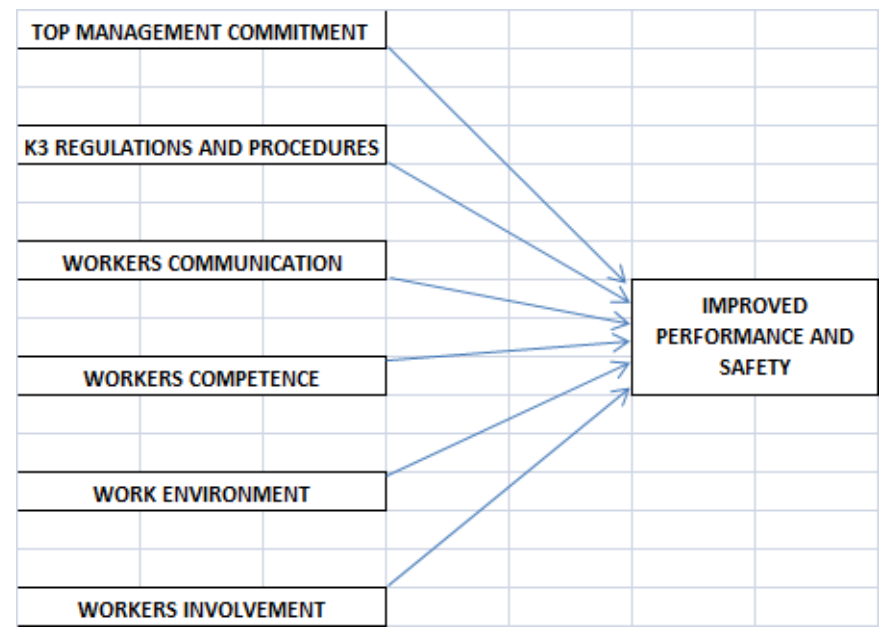

Figure 1 - Improved performance and safety

According to Wieke Y.C. et al (2012:85), occupational health and safety culture may be observed from several indicators, namely as follows:

1. Manager's commitment to workers. To start an occupational safety programs, top management to formulate a policy which shows their commitment to occupational safety issues. This initial step will determine the next policy making in terms of occupational safety.

2. The existence of $\mathrm{K} 3$ Regulations and Procedures. Companies that have occupational safety culture will have regulations and procedures governing K3. The procedure is a description of steps needed to achieve a situation or resolving tasks, in this case the security task and to achieve a secure situation. The regulations concern things that may or may not be done, and what must be done along with their penalties.

Companies with occupational safety culture would have procedures and regulations that are understood by their employees and may be reasonably practiced by the employees. This regulation should have strict penalties against their violations.

These regulations and procedures should be updated regularly in accordance to the company's situations.

If the company implements regulations and procedures that are not in accordance to the conditions of the construction projects, nor is it difficult to apply to the work, then the workers would be compelled to violate those occupational safety regulations and procedures established by the company.

3. The existence of a communication channel. Occupational safety programs should be supported by a good information management system in terms of gathering and delivering information, which includes the existence of good information channels from the management to workers and vice versa.

4. Workers Competence, namely the abilities possessed by the workers. Workers with a good level of competence are expected to be able to minimize work accidents and may assist in increasing the other workers' competence in occupational safety.

5. Working environment. The condition of a conducive working environment can support the application of an optimal occupational safety programs if all workers prioritize these occupational safety programs, and with an increasingly conducive work environment, it is expected to increase the workers' motivation.

6. The involvement of workers in K3. Workers who are aware of the importance of occupational safety programs will apply them wholeheartedly and without coercion, and feel that occupational safety programs are the right of the workers, instead of an obligation to do their jobs.

Performance increase may be reviewed from the criteria as follows: workers are able to work according to the target; timeliness in carrying out tasks; there is no work accident in the working environment; there are no errors in the working environment; attendance according to the work schedule (Wieke Y.C., 2012). 
According to Mangkunegara (2009: 67), employee performance is the result of work in quality and quantity achieved by an employee in carrying out his duties in accordance with the responsibilities given to him. Performance measures for a factory manager consist of various criteria. One of them is occupational health and safety, namely the level of frequency of seriousness of workplace accidents.

Occupational Health and Safety is not only aimed at achieving high levels of occupational health and safety, or just to prevent the possibility of workplace accidents, as well as occupational diseases. More than that, $\mathrm{K} 3$ has a vision and mission far ahead, namely to realize a healthy, safe, productive, prosperous workforce with good performance.

Occupational safety and health are important for the company, since the impact of accidents and occupational diseases not only harms employees, but also companies both directly and indirectly. Work safety means the process of planning and controlling potential situations that lead to workplace accidents through the preparation of standard operating procedures that are used as references in work (Rika Ampuh Hadiguna, 2009). Prabu Mangkunegara (2001) defines occupational health as a condition free from physical, mental, emotional or pain disorders caused by working environments.

This research intends to understand the phenomenon experienced by the research subject, for instance behavior, perception, motivation, action, et cetera, by applying qualitative approach. Qualitative research is a research by description in the form of words and language through the utilization of various scientific methods. There are two studies being reviewed in this research: by Saloni Waruwu et al (2016) and Subhan Zul Ardi et al (2018). It is necessary to add here that both researches have yet to show the factual implementation to achieve the goals. Here we would take a factual example on how a project is implementing K3 that supports in achieving the aimed continuous work culture.

This research has been undertaken and implemented in accordance with scientific procedures, but still has the limitations of:

- Factors influencing the Company Culture are yet to be specifically described, this research only has three variables, the management commitment, communication, and competence, whilst there are other factors that may have influences, such as the employees code of conduct, the availability of safety facilities;

- There is yet any specific data on how to increase the variable indicators to produce a consistent and continuous work culture.

The suggestions given for the any future research are as follows:

- Further research is required to discover any factor that might influences the work health and safety culture, and factors that influence the performance of a construction project;

- Further research is necessary to apply an evaluation standard for work health and safety culture in a construction project by referring to the number of accidents or violations committed by the construction workers;

- Further research is necessary to discover the benefits received by the company with the increase of company performance using case study research method and optimization analysis method to acquire an optimal profit;

- Future researchers should have better research model and by strong theories by having more references on construction works to support their researched topics.

\section{REFERENCES}

1. Organizational Culture and Effectiveness: Can American Theory Be Applied in Russia? By: Carl F. Fey and Daniel R. Denison William Davidson Institute Working Paper Number 598 July 2003.

2. The Guidance for the Management of Safety for Construction Works in Japanese ODA Projects September 2014 Japan International Cooperation Agency (JICA).

3. Occupational Safety and Health Administration (OSHA) US Department of Labour. 
4. Undang-undang No. 1 tahun 1970 tentang Keselamatan Kerja. Peraturan Menteri Tenaga Kerja and Transmigrasi No. PER.01/MEN/1980 Tentang Keselamatan and Kesehatan Kerja Pada Konstruksi Bangunan.

5. Dewi, Rijuna 2006 Pengaruh Keselamatan and Kesehatan Kerja terhadap Kinerja Karyawan pada PT. Ecogreen Oleochemicals Medan Plant. Skripsi Fakultas Ekonomi Universitas Sumatera Utara, Medan.

6. Kadin. 2002. Industri Jasa Konstruksi di Indonesia. Kompartemen Jasa Konstruksi, Konsultasi, Real Estate and Teknologi Tinggi, Kadin Indonesia, Jakarta.

7. Mangkunegara, A.P (2009) Manajemen Sumber daya manusia perusahaan, Bandung: Remaja Rosdakarya.

8. Mondy W.R. (2010), Manajemen Sumber Daya Manusia, Jakarta: Erlangga.

9. Mangkunegara, Anwar Prabu. 2009. Evaluasi Kinerja SDM. Bandung Refika Aditama.

10. Paulus, N. 1985. Manajemen Proyek.

11. Reason, J. T. 1997. Managing the Risk of Organizational Accidents. Ashgate Publishing Ltd. Aldershot, Hants.

12. Rika Ampuh Hadiguna. (2009). Manajemen Pabrik. Jakarta: Bumi Aksara.

13. Wicaksono, Iman Kurniawan and Singgih Moses L. 2011. Manajemen Resiko K3 (Keselamatan and Kesehatan Kerja) Pada Proyek Pembangunan Apartemen Puncak Permai Surabaya. Prosiding Seminar Nasional Manajemen Teknologi XIII. Institut Teknologi Sepuluh November.

14. Yuni, Wieke Christina, dkk. 2012. Pengaruh Budaya K3 Terhadap Kinerja Proyek Konstruksi. Universitas Brawijaya Malang. 